\title{
TEKNIK IMOTILISASI IKAN KERAPU CANTANG (Epinephelus sp.) MENGGUNAKAN EKSTRAK DAUN KECUBUNG (Datura metel L.)
}

\author{
Imotilization Techniques Of Cantang Grouper (Epinephelus sp.) Using Kecubung Leaf \\ Extract (Datura metel L.)
}

\author{
Rusdi Akbar ${ }^{1)}$, Jumsurizal ${ }^{1{ }^{*}}$, R. Marwita Sari Putri ${ }^{1)}$ \\ ${ }^{1)}$ Program Studi Teknologi Hasil Perikanan, Fakultas Ilmu Kelautan dan Perikanan, \\ Universitas Maritim Raja Ali haji, Tanjungpinang, 2911, Indonesia \\ *korespondensi: jumsurizal2@gmail.com
}

Diterima: 13 Februari 2021; Disetujui: 13 April 2021

\begin{abstract}
The immotilization technique of cantang grouper (Epinephelus sp.) Using Datura metel L. leaf extract. The purpose of this study was to find the best concentration at onset time of Datura metel $\mathrm{L}$. leaves as anesthetic agent for grouper (Epinephelus sp.) And its survival rate. The results of the study, using extracts of natural anesthetic ingredients of amethyst leaves with concentrations of $20 \%, 25 \%$, and $30 \%$ had different effects $(P<0.05)$ on the onset time and recovery of grouper fish. In this study, it provides a life passing rate of $100 \%$ at concentrate $20 \%$, and $25 \%$, while concentrate $30 \%$ has a $66.67 \%$ survival rate. The best concentration in this study was concentrate $30 \%$, with an onset time of 32.07 minutes with a recovery time of 9.07 minutes. This study used a non-factorial completely randomized design (CRD).
\end{abstract}

Keywords: concentration, Datura metel L. leaf, Epinephelus sp., immotilization

\begin{abstract}
ABSTRAK
Teknik imotilisai ikan kerapu cantang (Epinephelus sp.) menggunakan ekstrak daun kecubung (Datura metel L). Tujuan penelitian ini untuk mencari konsentrasi terbaik waktu onset daun kecubung sebagai zat anastesi kerapu cantang (Epinephelus sp.) dan tingkat kelangsungan hidupnya. Hasil penelitian yang dilakukan, menggunakan ekstrak bahan anastesi alami daun kecubung dengan kosentrasi $20 \%, 25 \%$, dan 30\% memiliki pengaruh yang berbeda $(P<0.05)$ pada waktu onset dan pulih ikan kerapu cantang. Pada penelitian ini memberikan tingkat kelulusan hidup $100 \%$ pada konsentrasi $20 \%$, dan $25 \%$, sedangkan konsentrasi $30 \%$ memiliki $66.67 \%$ tingkat kelulusan hidup. Kosentrasi terbaik pada penelitian ini yaitu kosentrasi $30 \%$, dengan waktu onset yaitu selama 32.07 menit dengan waktu pulih selama 9.07 menit. Penelitian ini menggunakan Rancangan Acak Lengkap (RAL) non Faktorial.
\end{abstract}

Kata kunci: daun kecubung, Epinephelus sp., imotilisasi, konsentrasi

\section{PENDAHULUAN}

Transportasi merupakan kegiatan utama untuk memindahkan suatu objek dari satu tempat ke tempat yang lain. Salah satu transportasi yang dilakukan yaitu trasnportasi ikan hidup yang dilakukan dengan tujuan untuk melakukan budidaya atau konsumsi ikan segar. Dalam pengangkutan ikan hidup salah satu kendala yang dihadapi adalah aktivitas metabolisme ikan. Ikan dalam kondisi yang tenang dapat mengurangi stress, menekan kecepatan metabolisme dan konsumsi oksigen. Kondisi ini akan memugkinkan ikan selama transportasi dengan kematian yang rendah, sehingga jarak transportasi akan lebih jauh dan kapasitas untuk pengangkutan dapat meningkat, (Maraja et al. 2017). Salah satu upaya untuk mengantisipasi ikan stres dapat dilakukan dengan menekan aktifitas metabolisme tubuh ikan serta menekan 
tingkat konsumsi oksigen selama proses transportasi, namun tetap mempertimbangkan aspek keamanan dan kesehatan ikan, (Farida et al. 2015). Upaya yang dilakukan dikenal dengan imotilisasi.

Teknik imotilisasi dengan zat anestesi merupakan salah satu teknik pemingsanan yang dilakukan menggunakan bahan kimia dan bahan alami yang mampu memberikan ketidaksadaran pada ikan yang akan ditransportasikan. Namun penggunaan bahan kimia pada ikan memberikan efek negatif bagi ikan maupun bagi manusia. Bahan kimia sebagai zat anestesi dapat memberikan residu yang berbahaya bagi kelangsungan hidup ikan, manusia, dan lingkungan, (Saskia et al. 2012).

Penggunaan zat anestesi sudah banyak dilakukan dalam proses transportasi ikan. Tanaman kecubung (Datura metel L.) merupakan salah satu tanaman yang memiliki kandungan senyawa sebagai anestesi alami yang dapat memberikan efek tidak sadar pada ikan, (Chotimah et al. 2009).

Ikan kerapu (Epinephelus sp.) merupakan ikan yang menjadi komoditas ekspor. Ikan kerapu cantang adalah salah satu jenis ikan yang banyak dibudidaya dan merupakan salah satu komoditas ikan ekonomis penting yang terdapat di Provinsi Kepulauan Riau. Selain itu nilai jualnya juga cukup tinggi (Triana 2010).

\section{METODE PENELITIAN}

\section{Alat dan Bahan}

Alat yang diguakan untuk aklimatisasai ikan adalah akuarium, dan aerator. Alat yang digunakan untuk pembuatan media pemingsanan adalah blender, gelas ukur, kain blacu, botol, dan pengaduk. Alat yang digunakan untuk pemingsanan ikan adalah termometer, stopwatch, pipet tetes, alat tulis, aerator, akuarium atau toples, spektofotometer, multitester, GlucoDR AGM2100.

Bahan utama yang diguakan dalam penelitian ini adalah daun kecubung (Datura metel L.), ikan kerapu cantang (Epinephelus sp.) dengan ukuran 60 - 95 gram/ekor yang diperoleh dari Keramba Jaring Apung (KJA) Tanjung Lanjut Kota Tanjungpinang, aquades, dan air laut steril.

\section{Prosedur Kerja}

Tahap penelitian ini terdiri dari tiga tahap, yaitu penelitian tahap pertama pencarian pencarian dosis anestesi, tahap kedua yaitu aklimatisasi ikan, pembuatan media pingsan, dan pemingsanan ikan, tahap ketiga yaitu pengujian kualitas air terdiri dari DO, suhu, amonia, dan uji glukosa darah ikan pada setiap konsentrasi.

\section{Aklimatisasi Ikan Kerapu Cantang}

Adaptasi ikan kerapu terhadap lingkungan yang baru dilakukan sebelum dilakukan penelitian. Ikan kerapu dilakukan pemuasaan 1x24 jam sebelum dilakukan penelitian. Penggunaan akuarium dengan ukuran $60 \times 30 \times 30 \mathrm{~cm}^{3}$ sebagai wadah adaptasi ikan. Air yang digunakan pada penelitian ini merupaka air laut yang telah diendapkan selama dua hari. Aerasi dilakukan untuk meningkatkan kandungan oksigen.

\section{Pembuatan Media Pingsan}

Daun kecubung yang telah dibersihkan dan dipotong kecil-kecil ditimbang 500 gram kemudian ditambahkan pelarut akuades $1000 \mathrm{~mL}$ lalu dihaluskan. Ekstrak kasar tersebut disaring menggunakan kain blacu. Konsentrasi yang digunakan dalam penelitian ini adalah 0\% (kontrol), 20\%, 25 $\%$, dan $30 \%$.

\section{Pemingsanan Ikan}

Toples yang berisi 1 ekor ikan pada setiap perlakuan ditambahkan dengan 
ekstrak yang telah disediakan. Banyaknya air pada pemingsanan ikan yaitu sebanyak $1000 \mathrm{ml}$. Penambahan ekstrak dilakukan setiap 30 detik sekali sebanyak $0,5 \mathrm{ml}$ hingga ikan roboh. Parameter yang diamati adalh tingkah laku ikan, perubahan kualitas air sebelum ikan dimasukkna dan setelah pingsan, waktu onset (waktu yang dibutuhkan hingga ikan pingsan), waktu pulih (waktu yang dibutuhkan hingga ikan sadar), dan tingkat kelulusan hidup ikan (survival rate).

Pengujian yang dilakukan adalah kadar glukosa darah dan kualitas air. Uji kualitas air terdiri dari pengukuran oksigen terlarut, pengukuran $\mathrm{pH}$, dan pengukuran kandungan amonia $\left(\mathrm{NH}_{3}\right)$.

\section{Pengukuran Kandungan Oksigen Terlarut (APHA 1975)}

Pengukuran ini dilakukan dengan menggunakan multitester. Pengukuran oksigen terlarut dilakukan dengan pengecekan alat yang dicelupkan ke dalam wadah yang berisi air pada pemingsanan dari awalikan normal, ekstrak ditetesi, dan hingga ikan pingsan.

\section{Pengukuran Suhu (APHA 1975)}

Pengukuran suhu dilakukan dengan menggunakan $\mathrm{pH}$-meter. Pengukuran dilakukan dengan cara mencelupkan alat kedalam wadah pemingsanan yang telah berisi air dengan pembacaan berskala ke dalam akuarium yang telah berisi air. Pengukuran suhu dilakukan dari sebelum ikan dimasukkan kewadah pemingsanan, kemudian ikan dalam keadaan normal, dan ketika ikan pingsan.

\section{Total Amonia Nitrogen (APHA 1975)}

Sampel sebanyak $10 \mathrm{ml}$ didestilasi, lalu hasilnya ditambahkan $\mathrm{MnSO}_{4}$. Sampel ditambahkan $0,5 \mathrm{ml}$ asam hypoclorus dan $0,6 \mathrm{~mL}$ reagen phenate,kemudian diaduk. Akan terjadi perubahan warna kebbiruan dikarenakan penambahan reagen tersebut. Larutan blanko dan larutan standar dibuat selama pengukuran ini. Kemudian pengukuran nilai absorban pada blanko menggunakan spektofotometer dengan panjang gelombang $630 \mathrm{~nm}$.

\section{Analisis Data}

Analisis data akan dilakukan dengan menggunakan Rancangan Acak Lengkap (RAL). Perlakuan yang digunakan ada tiga perlakuan yaitu daun kecubung dosis $20 \%$, $25 \%$ dan $30 \%$ dengan 3 kali ulangan.

\section{HASIL DAN PEMBAHASAN}

\section{Persiapan Hewan Uji}

Transportasi ikan memperhatikan kualitas ikan yang akan ditransportasikan menjadi nilai utama. Menurut Berka (2005), kualitas ikan yang buruk akan mempengaruhi tingkat kematian yang lebih besar di bandingkan dengan kualitas ikan yang lebih baik atau dalam kondisi sehat. Ikan yang akan digunakan dalam pemingsanan ini yaitu ikan kerapu cantang (Epinephelus sp.) yang memiliki berat sekitar 65 - 94 gram. Ikan diadaptasi selama 1 hari dan diberikan pakan ikan sebelum dikakukan pemuasaan 1 × 24 jam yang bertujuan untuk mengeluarkan sisa metabolisme dari sisa pakan yang akan dimuntahkan atau dikeluarkan melalui feses, (Ismi et al. 2016).

\section{Kualitas Air Media Pemeliharaan Kerapu}

Air yang digunakan selama proses ikan kerapu cantang menggunakan air laut dari lingkungan hidup ikan yang berlokasi di Tanjung Lanjut yang telah diendapkan selama 2 hari. Pengendapan ini bertujuan agar kotoran yang terdapat di dalam air mengendap.

Suhu air laut di keramba jaring apung yaitu $27,3{ }^{\circ} \mathrm{C}$ sedangkan pada air laut yang diendapkan selama 2 hari $27,6{ }^{\circ} \mathrm{C}$. Suhu 
yang tidak ada perubahan secara signifikan tersebut masih baik digunakan untuk media hidup ikan. Menurut Jain et al. (2013) perubahan suhu hingga $10{ }^{\circ} \mathrm{C}$ dapat meningkatkan metabolisme, respirasi dan kebutuhan oksigen yang membuat ikian stres dan mati. Air laut dari lingkungan keramba jaring apung ikan kerapu cantang memiliki nilai $\mathrm{pH} 8,05$ dan air laut telah diendapkan di dalam akuarium selama $2 \mathrm{x}$ 24 jam memiliki nilai $\mathrm{pH}$ sebesar 8,21. Nilai $\mathrm{pH}$ tersebut masih dalam rentang standar lingkungan hidup ikan kerapu cantang. Dissolve oxsygen (DO) adalah faktor penting dalam kelangsungan hidup ikan. Oksigen terlarut yang sedikit pada perairan akan berpengaruh terhadap kelangsungan hidup dan pertumbuhan ikan. Suhu merupakan faktor yang mempengaruhi konsentrasi oksigen terlarut, (Mubarak 2010). Kandungan amonia $\left(\mathrm{NH}_{3}\right)$ air laut yang berasal dari lingkungan keramba jaring apung ikan kerapu cantang menunjukan nilai sebesar 1,21 ppm dan air laut dari lingkungan keramba jaring apung yang telah diendapkan menunjukan nilai kandungan amonia yaitu $<0,05 \mathrm{ppm}$. Hasil analisis kualitas air laut pada keramba jaring apung ikan kerapu cantang telah memenuhi standar pada Suhu, DO, pH sedangkan TAN tidak memenuhi standar untuk pertumbuhan ikan kerapu cantang. Hasil analisis dapat dilihat pada Tabel 1 .

\section{Pengamatan tingkah laku ikan selama pingsan}

Pengamatan perubahan tingkah laku ikan dilakukan setiap 2 menit sekali, dari menit ke-0 sampai ikan tidak sadar. Ikan yang tidak sadar ditandai dengan tubuh ikan berada didasar dengan posisi terbalik, operculum dan ingsang bergerak sangat lambat serta respon terhadap rangsangan luar menghilang kecuali dengan tekanan yang kuat. Pengamatan dapat dilihat pada Tabel 2.

\section{Waktu onset pemingsanan ikan kerapu cantang (Epinephelus sp.)}

Waktu onset adalah waktu saat biota diberikan obat hingga obat terasa kerjanya, (Ningsih dan Widyaningrum 2014). Waktu onset dalam penelitiam ini dicatat dalam 2 menit sekali dimulai dari 0 hingga ikan mulai kehilangan kesadaran.

Waktu onset pada penelitian ini berbeda-beda karena adanya pemberian kosentrasi ekstrak daun kecubung yang berbeda-beda. Hasil pengujian waktu pingsan ikan kerapu cantang pada kosentrasi $20 \%$ yaitu 63,07 menit, $25 \%$ yaitu 53,33 menit dan kosentrasi $30 \%$ yaitu 32,07 menit.

Waktu onset tercepat dalam penelitian ini adalah konsentrasi $30 \%$. Hasil penelitian tersebut menunjukkan bahwa semakin tinggi ekstrak kosentrasi daun kecubung, maka semakin cepat pula waktu pingsan ikan kerapu cantang. Hal ini sesuai dengan pernyataan Munandar et al. (2017), semakin tinggi konsentrasi maka waktu yang dibutuhkan untuk pemingsanan semakin cepat.

Tabel 1. Hasil Analisis Kualitas Air Media Pemeliharaan Ikan Kerapu Cantang (Epinephelus sp.)

\begin{tabular}{lccl}
\hline Parameter Uji & $\begin{array}{c}\text { Air Lingkungan Keramba } \\
\text { Ikan Kerapu Cantang }\end{array}$ & $\begin{array}{c}\text { Air Laut Pengendapan } \\
\text { Selama 2 hari }\end{array}$ & BSN (2014) \\
\hline Suhu $\left({ }^{\circ} \mathrm{C}\right)$ & 27,30 & 27,6 & $28-32{ }^{\circ} \mathrm{C}$ \\
DO $(\mathrm{ppm})$ & 8,40 & 8,1 & Minimal $4 \mathrm{ppm}$ \\
pH & 8,05 & 8,21 & $7,5-8,5 \mathrm{ppm}$ \\
TAN $(\mathrm{ppm})$ & 1,21 & $<0,05$ & Maksimal 0,01 ppm \\
\hline
\end{tabular}


Tabel 2. Pengamata tingkah laku ikan selama pingsan

\begin{tabular}{ccllc}
\hline Waktu (Menit) & Tingkat & \multicolumn{1}{c}{ 20\% } & \multicolumn{1}{c}{$\mathbf{2 5 \%}$} & \multicolumn{1}{c}{$\mathbf{3 0 \%}$} \\
\hline $32-34$ & $2 \mathrm{a}$ & $\begin{array}{l}\text { Kehilangan } \\
\text { keseimbangan sebagian }\end{array}$ & $\begin{array}{l}\text { Kehilangan } \\
\text { keseimbangan total }\end{array}$ & Roboh $(32.07)^{*}$ \\
$52-54$ & 3 & $\begin{array}{l}\text { Gerakan tidak ada } \\
\text { Roboh (63.04) }\end{array}$ & Roboh $(53.33)^{*}$ & \\
$62-64$ & 4 & & & \\
\hline
\end{tabular}

Hasil pengamatan waktu onset pada penelitian anastesi ikan kerapu cantang (Epinephelus sp.) dapat dilihat pada Gambar 1.

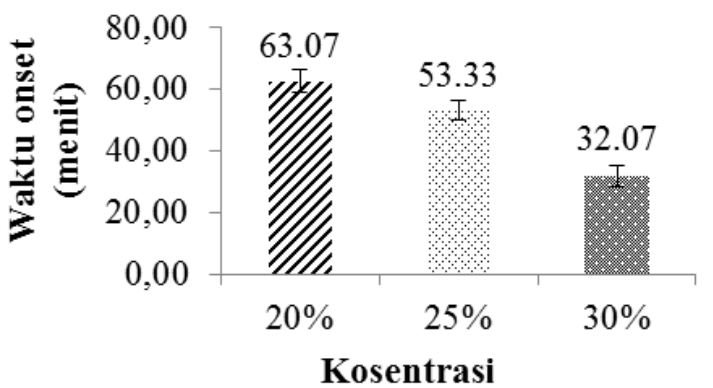

Gambar 1. Histogram pengaruh konsentrasi ekstrak daun kecubung (Datura metel L.) pada waktu onset ikan kerapu cantang (Epinephelus sp.)

Waktu yang baik untuk anastesi ikan adalah anastesi yang dapat memingsankan ikan kurang dari tiga menit, (Guun 2001). Waktu Onset yang ditimbulkan akibat pemberian daun kecubung (Datura metel L.) kurang memuaskan karena waktu yang baik untuk memingsankan ikan dengan bahan anastesi adalah tiga menit.

\section{Waktu pulih ikan kerapu cantang (Epinephelus sp.)}

Waktu pulih atau waktu sadar ikan setelah dipingsankan merupakan waktu yang dibutuhkan ikan untuk pulih kembali dengan bantuan aerator yang kuat di dalam aquarium yang berisikan air laut yang telah diendapkan sebagai media pemulihan ikan. Pemulihan dilakukan dengan cara memasukkan ikan kerapu cantang (Epinephelus sp.) yang telah diberi bahan anastesi dengan kosentrasi $20 \%, 25 \%$, dan $30 \%$ kedalam aquarium yang telah diberi aerator. Hal ini sesuai dengan pernyataan
Neiffer dan Stamper (2009), yang menjelaskan bahwa selama pembugaran ikan perlu dilakukan dengan menggunakan air yang mengalir pada ikan atau menempatkan ikan yang telah pingsan kedalam bak yang berisi air dan aerator sangat dianjurkan karena metabolit ikan kerapu cantang (Epinephelus sp.) dapat dieksresikan ke dalam air sehingga bahan anastesi tidak terserap kembali oleh insang maupun mulut.

Hal ini menunjukkan hasil penelitian menggunakan ekstrak daun kecubung (Datura metel L.) pada kosentrasi yang paling tinggi menunjukkan waktu pulih ikan kerapu cantang cantang (Epinephelus sp.) yang lebih lama dan sebaliknya pada konsentrasi yang lebih rendah waktu pulih ikan semakin cepat. Hal ini disebabkan oleh zat metabolit skunder dari ekstrak daun kecubung yang masuk kedalam tubuh ikan lebiih tinggi sehingga diperlukan waktu yang lebih lama untuk menetralisir zat tersebut.

Hasil Pengamatan waktu pulih ikan kerapu cantang (Epinephelus sp.) menggunakan ekstrak daun kecubung (Datura metel L.) dapat dilihat pada Gambar 2.

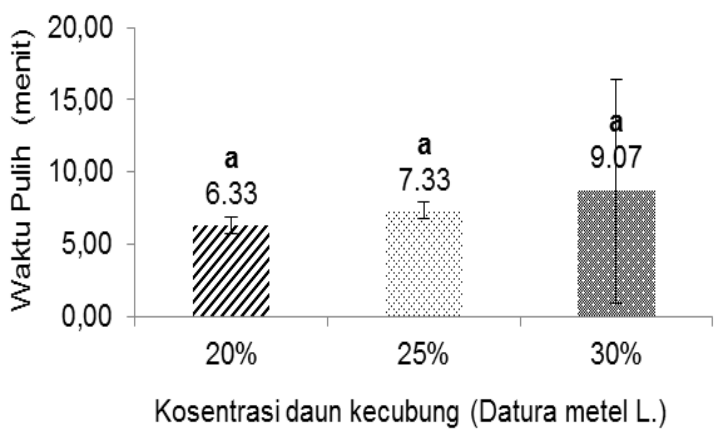

Gambar 2. Histogram Pengaruh Kosentrasi Ekstrak Daun Kecubung (Datura metel L.) Pada Waktu Pulih Ikan Kerapu Cantang (Epinephelus sp.) 
Gambar 2. dapat dilihat bahwa waktu pulih atau waktu sadar ikan kerapu cantang cantang (Epinephelus sp.) dengan kosentrasi $20 \%$, 25\%, dan $30 \%$ adalah 6.33 , 7.33, dan 9.07 menit. Perbedaan waktu sadar menunjukkan bahwa semakin rendah kosentrasi anastesi yang diberikan maka semakin cepat pula waktu yang dibutuhkan untuk ikan pulih kembali seperti saat sebelum diberikan bahan anastesi. Hal ini sesuai dengan pernyataan Hasan et al. (2016) yang menunjukan bahwa semakin rendah konsentrasi maka semakin cepat ikan tersebut pulih sadar.

\section{kelulusan hidup ikan kerapu cantang}

Kelulusan hidup ikan atau Survival rate ditentukan dengan cara berapa banyak ikan kerapu cantang (Epinephelus sp.) yang pulih kembali di dalam air dengan bantuan aerator selama beberapa menit. Pengujian ini dilakukan untuk mengetahui kosentrasi uji yang menimbulkan kematian yang tinggi pada ikan yang diuji, mengetahui aktivitas penggunaan ekstrak daun kecubung (Datura metel L.) sebagai bahan anetesi alami, dan konsentrasi yang memberikan tingkat kelulusan hidup ikan kerapu cantang (Epinephelus sp.).

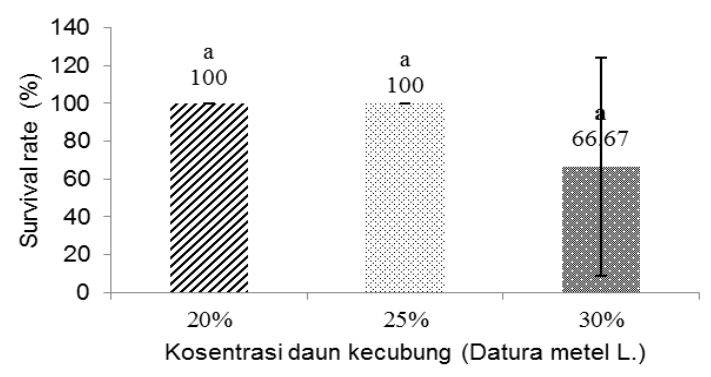

Gambar 3. Histogram Tingkat Survival Rate lkan Kerapu Cantang (Epinephelus sp.) Pada Waktu Anastesi

Pada Gambar 3. dapat dilihat bahwa tingkat kelulusan hidup ikan kerapu cantang (Epinephelus sp.) setelah pemberian ekstrak daun kecubung (Datura metel L.) dengan kosentrasi $20 \%$, 25\%, menghasilkan tingkat kelulusan hidup 100\%, dan konsentrasi 30\% menghasilkan tingkat kelulusan hidup $66,67 \%$ yang mana dalam 3 kali percobaan pemingsanan hanya 2 yang hidup. Tingkat kelulusan hidup ikan pada penelitian ini dilihat dari waktu bugar ikan yang telah diberikan ekstrak daun kecubung (Datura metel L.) dan ikan kembali normal.

Hal tersebut karena ssemakin tinggi kosentrasi yang diberikan, maka semakin tinggi pula kandungan alkaloid yang terkandung dalam media pingsan ikan kerapu cantang. Penyebab terjadinya kematian ikan uji desebabkan oleh pemberian konsentrasi yang tinggi, semakin tinggi konsentrasi maka semakin cepat proses penyerapan zat anestesi yang diserap oleh ikan uji (Maryani et al. 2018).

\section{Kualitas Air Media Pemingsanan Ikan Kerapu Cantang}

Pengujian kualitas air pada media pemingsanan ikan kerapu cantang dilakukan sebelum pemingsanan, setelah pemingsanan dan setelah pulih kembali. Pengujian kualitas air sebelum memasuki proses pemingsanan bertujuan untuk mengetahui kelayakan pada air, pengujian kualitas air setelah pemingsanan bertujuan untuk mengetahui pengaruh bahan anestesi terhadap karakter fisik kimia air, dan pengujian kulitas air yang dilakukan setelah ikan pulih kembali bertujuan untuk mengetahui kelangsungan hidup pada ikan.

Pengujian kualitas air ini selain untuk mengecek kualitas fisik dari bahan anestesi juga bertujuan untuk mengetahui pengaruhnya terhadap tingkat kesetresan ikan. Menurut Iwama et al. (2004), menyatakan bahwa pada kondisi ekstrim atau perubahan kualitas parameter air seperti dissolved oxygen (DO), amonia, $\mathrm{pH}$, dan suhu dapat menyebabkan meningkatnya stress pada ikan. 
Tabel 3. Hasil Analisis Kualitas Air

\begin{tabular}{ccrccc}
\hline $\begin{array}{c}\text { Pengamatan } \\
\text { Perlakuan }\end{array}$ & \multirow{2}{*}{ Konsentrasi } & \multicolumn{4}{c}{ Parameter Uji } \\
\cline { 2 - 6 } Sebelum & $0 \%$ & Suhu $\left({ }^{\circ} \mathbf{C}\right)$ & Do (ppm) & pH & TAN (ppm) \\
& $20 \%$ & $27,5 \pm 0,50$ & $7.6 \pm 0.10$ & $7.74 \pm 0.46$ & \\
& $25 \%$ & $27,1 \pm 0,17$ & $7,76 \pm 0,05$ & $7,65 \pm 0,35$ & $<0.05$ \\
& $30 \%$ & $26,93 \pm 0,70$ & $7,53 \pm 0,15$ & $7,73 \pm 0,25$ & \\
Setelah & $0 \%$ & $27,86 \pm 0,80$ & $7,10 \pm 1,13$ & $7,81 \pm 0,53$ & \\
& $20 \%$ & $27,03 \pm 0,49$ & $7,3 \pm 0,05$ & $7,54 \pm 0,34$ & $0,05 \pm 0,00$ \\
& $25 \%$ & $27,2 \pm 0,78$ & $7,3 \pm 0,28$ & $7,25 \pm 0,19$ & $0,30 \pm 0,01$ \\
& $30 \%$ & $27,3 \pm 0,30$ & $7,26 \pm 0,11$ & $6,85 \pm 0,48$ & $0,28 \pm 0,02$ \\
Pulih & $0 \%$ & $29,36 \pm 0,55$ & $5,67 \pm 0,20$ & $6,69 \pm 0,17$ & $0,24 \pm 0,01$ \\
& $20 \%$ & $27,26 \pm 0,28$ & $7,43 \pm 0,11$ & $7,72 \pm 0,18$ & \\
& $25 \%$ & $27 \pm 0,51$ & $7,6 \pm 0,10$ & $8,19 \pm 0,14$ & $<0,05$ \\
& $30 \%$ & $27,03 \pm 0,40$ & $7,4 \pm 0,20$ & $7,45 \pm 0,30$ & \\
\hline \multirow{4}{*}{} & $27,65 \pm 0,91$ & $7,3 \pm 0,84$ & $7,92 \pm 0,77$ & \\
\hline
\end{tabular}

Hasil analisis kualitas air media pemingsanan ikan kerapu cantang (Epinephelus sp.) dapat dilihat pada Tabel 3. Pada Tabel 3 dapat dilihat bahwa Nilai parameter suhu, Do, pH dan TAN (Total Amonia Nitrogen) pada perlakuan sebelum pemingsanan, setelah pemingsanan dan setelah pulih kembali mendapatkan hasil yang tidak terlalu berbeda jauh. Hal tersebut karena air yang digunakan sebagai media pemingsanan menggunakan air laut yang berasal dari lingkungan ikan kerapu cantang yang sama dan telah diendapkan didalam aquarium selama 2 hari.

Suhu yang dihasilkan pada kosentrasi $0 \%, 20 \%, 25 \%$ dan $30 \%$ berturut-turut sebelum pemingsanan yaitu $27,5{ }^{\circ} \mathrm{C}, 27,1$ ${ }^{\circ} \mathrm{C}$, 26,93 ${ }^{\circ} \mathrm{C}$ dan $27,86{ }^{\circ} \mathrm{C}$, saat setelah pemingsanan menunjukkan peningkatan suhu pada kosentrasi $0 \%, 20 \%, 25 \%$, dan $30 \%$ yaitu $27.03{ }^{\circ} \mathrm{C}, 27,2{ }^{\circ} \mathrm{C}, 27,3{ }^{\circ} \mathrm{C}$, dan $29,36{ }^{\circ} \mathrm{C}$, sedangkan pada saat pemulihan suhu pada kosentrasi $0 \%, 20 \%, 25 \%$, dan $30 \%$, mengalami penurunan kembali yaitu $27,26{ }^{\circ} \mathrm{C}, 27{ }^{\circ} \mathrm{C}, 27,03{ }^{\circ} \mathrm{C}$, dan $27,65{ }^{\circ} \mathrm{C}$. Penurunan suhu pada kosentrasi $0 \%, 20 \%$, $25 \%$ dan $30 \%$ hal tersebut terjadi dikarenakan ikan mulai pulih atau normal kembali.

Nilai DO pada kosentrasi $0 \%, 20 \%$, $25 \%$, dan $30 \%$ sebelum pemingsanan yaitu 7.6 ppm, 7.76 ppm, 7.55 ppm, dan 7.1 ppm, saat setelah pemingsanan terjadi penurunan DO pada kosentrasi $0 \%, 20 \%, 25 \%$, dan $30 \%$ yaitu ppm, 7.3 ppm, 7.26 ppm, dan 5.67 ppm, sedangkan pada saat pemulihan DO pada kosentrasi $0 \%, 20 \%, 25 \%$ dan $30 \%$ naik kembali yaitu menunjukkan pada angka 7.43 ppm, 7.6 ppm, 7.4 ppm, dan 7.3 ppm. Penurunan nilai DO sebelum dan sesudah pemingsanan ini terjadi karena adanya pemanfaatan oksigen dari ikan kerapu cantang (Epinephelus sp.) dan aktivitas ikan yang aktif. Peningkatan konsumsi oksigen menjelang ikan pingsan menyebabkan penurunan nilai DO (Aini et al. 2010). Kisaran nilai DO sesudah pemingsanan dengan pemberian ekstrak daun kecubung pada penelitian ini masih memenuhi standar bagi tingkat kelangsungan hidup ikan kecapu cantang. Menurut BSN (2014), kandungan oksigen terlarut di dalam air yang sesuai untuk pertumbuhan ikan kerapu cantang yaitu minimal 4 ppm.

Nilai $\mathrm{pH}$ pada kosentrasi $0 \%, 20 \%, 25 \%$ dan $30 \%$ sebelum pemingsanan yaitu 7.74 , $7.65,7.73$, dan 7.81, saat setelah pemingsanan terjadi penurunan nilai $\mathrm{pH}$ pada kosentrasi $0 \%, 20 \%$, 25\%, dan $30 \%$ yaitu $7.54,7.25,6.85$, dan 6.69 , sedangkan pada saat pemulihan $\mathrm{pH}$ pada kosentrasi $0 \%$, 20\%, 25\%, dan 30\% naik kembali menunjukkan nilai $\mathrm{pH} 7.72,8.19,7.45$, dan 7.92. Menurut Harahap (2014), penurunan 
nilai $\mathrm{pH}$ terjadi karena air bercampur dengan karbondioksida yang menghasilkan karbonat. Penurunan nilai $\mathrm{pH}$ disebabkan oleh daun kecubung dan kadar $\mathrm{CO}_{2}$. Proses metabolisme ikan menyebabkan peningkatan kadar $\mathrm{CO}_{2}$. Proses metabolisme akan meningkat menjelang ikan pingsan (Yanto 2012).

Nilai TAN dari hasil pengujian kualitas air sebelum dilakukan pemingsanan pada konsentrasi $0 \%, 20 \%, 25 \%$, dan $30 \%$ menujukan angka $<0,05 \mathrm{ppm}$ dan saat setelah dilakukan pemingsanan nilai TAN meningkat pada kosentrasi $20 \%, 25 \%$, dan $30 \%$ yaitu 0.3 ppm, 0.28 ppm, dan 0.24 ppm. Hasil ini menunjukkan bahwa nilai TAN meningkat setelah proses pemingsanan. Hal ini terjadi karena selama pemberian bahan anestesi respirasi ikan kerapu cantang mengalami peningkatan dan membuang metabolisme yang berlebihan. Proses metabolisme saat proses pemingsanan akan meningkatkan nilai TAN dipengaruhi oleh terakumulasinya zat sisa yang terjadi selama proses pemingsanan (Yanto 2012). Naiknya nilai TAN pada penelitian ini tidak mempengaruhi hidup ikan kerapu cantang selama proses pemingsanan dikarenakan masih terdapat fakor-faktor lain yang mendukung kelangsungan hidup ikan yaitu suhu, DO, $\mathrm{pH}$ dan $\mathrm{CO}_{2}$. Menurut BSN (2014), limit maksimum konsentrasi ikan kerapu cantang adalah 0,01 ppm.

\section{Analisis Glukosa Darah Ikan Kerapu Cantang (Epinephelus sp.)}

Pengujian glukosa darah pada ikan kerapu cantang bertujuan untuk mengetahui kadar glukosa darah pada ikan dengan menggunakan alat indikator glukosa darah merk GlucoDr AGM 2100. Glukosa darah ikan adalah salah satu parameter pengujian untuk mengukur tingkat keseteresan pada ikan. Pengujian kadar glukosa dalam penelitian ini dilakukan sebanyak 3 kali yaitu sebelum ikan pingsan, ketika ikan pingsan dan ketika ikan pulih kembali.

Hasil analisis kadar glukosa darah ikan kerapu catang dapat dilihat pada Tabel 4. Berdasarkan Tabel tersebut nilai glukosa ikan kerapu cantang pemingsanan pada perlakuan kosentrasi $0 \%$ adalah sebesar $37.33 \mathrm{mg} / \mathrm{dL}$, sedangkan pada perlakuan menggunkan bahan anastesi kosentrasi $20 \%$ nilai kadar gula darah ikan kerapu cantang yaitu $40.33 \mathrm{mg} / \mathrm{dL}$, kosentrasi $25 \%$ yaitu sebesar $40.33 \mathrm{mg} / \mathrm{dL}$ dan kosentrasi $30 \%$ yaitu sebesar $38 \mathrm{mg} / \mathrm{dL}$. Pengukuran nilai kadar glukosa darah ketika mengalami pingsan pada perlakuan menggunakan bahan anastesi kosentrasi $20 \%$ menunjukkan nilai glukosa darah yang tinggi sebelumnya yaitu $93 \mathrm{mg} / \mathrm{dL}$, kosentrasi $25 \%$ sebesar $84.66 \mathrm{mg} / \mathrm{dL}$ dan kosentrasi $30 \%$ yaitu $81 \mathrm{mg} / \mathrm{dL}$. Peningkatan kadar glukosa darah tersebut masih dalam kisaran normal glukosa darah ikan kerapu cantang 33-250 mg/dL, (Edison et al. 2017). Menurut Subandiyono et al. (2003), ikan menjadi stress akan meningkatkan kadar glukosa darah ikan tersebut.

Tabel 4. Analisis Glukosa Darah Ikan Kerapu Cantang (Epinephelus sp.)

\begin{tabular}{ccccc}
\hline \multicolumn{5}{c}{ Nilai Glukosa Darah Ikan (mg/dL) } \\
\hline \multirow{4}{*}{ Konsentrasi } & \multicolumn{4}{c}{ Perlakuan Anestesi } \\
\cline { 2 - 5 } & $\begin{array}{c}\text { Sebelum } \\
\text { Pemingsanan }\end{array}$ & Setelah Pingsan & Pulih & $\begin{array}{c}\text { Edison et al. } \\
(\mathbf{2 0 1 7})\end{array}$ \\
\hline $20 \%$ & $40,33 \pm 1,52$ & $93 \pm 2$ & $41,66 \pm 0,57$ & \\
$25 \%$ & $40,33 \pm 0,57$ & $84,66 \pm 0,57$ & $39,33 \pm 0,57$ & $33-250(\mathrm{mg} / \mathrm{dL})$ \\
$30 \%$ & $38 \pm 3,60$ & $81 \pm 2,64$ & $37,66 \pm 1,15$ & \\
\hline
\end{tabular}




\section{KESIMPULAN}

Konsentrasi terbaik pada penelitian ini yaitu konsentrasi $30 \%$ dengan waktu onset terbaik yaitu 28 menit. Semakin tinggi kosentrasi ekstrak yang diberikan maka proses pemingsanan ikan akan semakin cepat begitu pula sebaliknya semakin rendah kosentrasi ekstrak daun yang diberikan maka proses pemingsanan ikan akan semakin lama, dikarenakan tinggi rendahnya kandungan senyawa yang terkandung sangat berpengaruh terhadap proses pemingsanan ikan kerapu cantang.

\section{DAFTAR PUSTAKA}

Aini, M., Ali, M., Putri, B. 2014. Penerapan teknik imotilisasi benih nila (Oreochromis niloticus) menggunakan ekstraksi daun bandotan (Ageratum conyzoides) pada transportasi basah. Jurnal Rekayasa dan Teknologi Budidaya Perairan. 11(2): 217-226.

APHA. 1975. American Public Health Association. Standar Methods for The Eximination of Water and Wastewater 14th Edition. New York (US): American Public Health Association.

Berka, R. 2005. The transport of live fish a review. EIFAC Tech. Pap. Food agriculture organization of the unated nations. International Journal of Green Pharmacy. 10(48): 52-53.

BSN. 2014. Ikan Kerapu Cantang (Epinephelus fuscoguttatus, Forsskal $1775>$ Epinephelus lanceolatus, Bloch 1790). SNI 8036. 2:2014.

Chotimah, D.N., Tjahjaningsih, W., Sulmartini, L., Thomas, V., Widiyatno., Triastuti, T. 2009. Respon daya cerna dan respirasi benih ikan mas (Cyprinus carpio) pasca transportasi dengan menggunakan daun bandotan (Ageratum conyzoides) sebagai bahan antimetabolik. Jurnal IImiah Perikanan dan Kelautan. 1(1): 79-86.

Edison, M.A., Thamrin., Ikhwan, S.Y. 2017. Analisis daya anastesi bahan alami ekstrak buah keben (Barringtonia asiatica) pada ikan bawal bintang (Trachinotus blochii). Jurnal Ilmiah Perikanan dan Kelautan. 5(3): 21-22.

Farida., Rachimi., Ramadhan, J. 2015. Imotilisasi benih ikan jelawat (Leptobarbus hoevani) menggunakan konsentrasi larutan daun bandotan (Ageratum conyzoides) yang berbeda pada transportasi tertutup. Jurnal Ruaya. 5: 22-28.

Guun, E. 2001. Floundering in the poibes of fish anestesia. Water Science and Technology. 15(8): 15-21.

Harahap, A.F. 2014. Teknik Imotilisasi Ikan Mas (Cryprinus Carpio) Menggunakan Ekstrak Daun Kecubung (Datura metel L). [Skripsi]. Institut Pertanian Bogor. Bogor.

Hasan, H., Raharjo, E.I., Zamri, S. 2016. Respon pemberian dosis minyak sereh (Cymbopogon citratus) untuk anestesi ikan botia (Chromobotia macracanthus bleeker) dengan metode transportasi tertutup. Jurnal Ruaya. 4(2): 7-12.

Ismi, S., Kusumawati, D., Asih, Y.N. 2016. Pengaruh lama waktu pemuasaan dan beda kepadatan benih kerapu pada transportasi secara tertutup. Jurnal IImu dan Teknologi Kelautan Tropis. 8(2): 625-632.

Iwama, G.K., Afonso, L.O.B., Todgham, A., Ackerman, P., Nakano, K. 2004. Are hsps suitable for indicating stressed states in fish. The Journal Experimental Biology. 207: 15-19.

Jain, S., Sharma, G., Mathur, Y.P. 2013. Effects of temperature variations on fish in lakes. International Journal of Engineering Research \& Technology. 2(10): 2516-2523. 
Maryani., Efendi, E., Utomo, D.S.C. 2018. Efektivitas ekstrak bunga kenanga (Cananga odorata) sebagai bahan anestesi pada transportasi benih nila merah (Oreochromis sp.) tanpa media air. Journal of Fisheries Science and Technology. 4(1): 8-15.

Mubarak, A.S., Utami, D.A.S., Kusdarwati, R. 2010. Korelasi antara konsentrasi oksigen terlarut pada kepadatan yang berbeda dengan skoring warna Daphnia spp. Jurnal IImiah Perikanan dan Kelautan. 2(1): 45-50.

Munandar, A., Indaryanto, F.R., Prestisia, H.N., Muhdani, N. 2017. Potensi ekstrak daun picung (Pangium edule) sebagai bahan pemingsan ikan nila (Oreochromis niloticus) pada transportasi sistem kering. Jurnal Teknologi Hasil Perikanan. 6(2): 107114.

Neifer, D.L., Stamper, M.A. 2009. Fish sedation, anesthesia, and analgesia, and euthanasia: considerations, methods, and types of drugs. ILAR Journal. 50(4). 343-360.

Ningsih, S., Widyaningrum, N.R. (2014). Kemampuan efek sedasi infusa umbi rumput teki (Cyperus rotundus $L$ ) pada mencit jantan ras swiss. Indonesian Journal On Medical Science. 1(2): 5573.

Saskia., Harpeni., Kadarini. 2012. Toksisitas dan kemampuan anestetik minyak cengkeh (Sygnium aromaticum) terhadap benih ikan pelangi merah (Glossolepis incisus). Jurnal IImu Perikanan dan Sumberdaya Perairan. 2(1): 83-88.

Subandiyono., Astuti, S.H., Supriyono, E., Mokoginta, I. 2003. Respon glukosa darah ikan gurami (Psphronemus gouramy, L/C.) terhadap stres perubahan suhu lingkungan. Jurnal Akuakultur Indonesia. (2):73-77.

Triana, S.H. 2010. Analisis fragmen dna ikan kerapu macan (Epinephelus fuscoguttatus) yang tahan dan rentan terhadap bakteri Vibrio alginolyticus. Jurnal Ilmu Dasar. 11(1): 8-16.

Yanto, H. 2012. Kinerja ms-222 dan kepadatan ikan botia (Botia macracanthus) yang berbeda selama transportasi. Jurnal Penelitian Perikanan. 1(1): 43-51. 